\title{
Prevalence of Headache After Spinal Anesthesia Among Brazilian Patients
}

\author{
Binda Neto $I^{1}$, Vaz $\mathrm{JLM}^{1}$, Oliveira CAB ${ }^{1}$, Alvarenga $\mathrm{RMP}^{2}$, Souza $\mathrm{JA}^{2}$, Mota-Binda $\mathrm{AL}^{3}$ and Ribeiro de \\ Noronha SM ${ }^{4 *}$ \\ ${ }^{1}$ Anesthesia Department, Brazil \\ ${ }^{2}$ Neurology Department, Brazil \\ ${ }^{3}$ Veiga de Almeida University, Brazil \\ ${ }^{4}$ Centro Universitário das Faculdades Metropolitanas Unidas, Brazil \\ *Corresponding author: Samuel Marcos Ribeiro de Noronha, Centro Universitário das Faculdades Metropolitanas Unidas (FMU)
} Av Sto Amaro, 1239-04505-002, Sao Paulo-SP, Brazil

\begin{tabular}{l}
\hline ARTICLE INFO \\
\hline Received: 幽 October 09, 2019 \\
Published: 幽 October 17, 2019 \\
\hline Citation: Binda Neto I, Vaz JLM, Olivei- \\
ra CAB, Alvarenga RMP, Souza JÁ, Mo- \\
ta-Binda AL, Ribeiro de Noronha SM. \\
Prevalence of Headache After Spinal An- \\
esthesia Among Brazilian Patients. Bi- \\
omed J Sci \& Tech Res 22(1)-2019. BJSTR. \\
MS.ID.003704.
\end{tabular}

\section{ABSTRACT}

Headache is one of the most common symptoms in medicine in general, and one of the most frequent complaints in clinical, gynecological, pediatric and neurological consultations. Spinal anesthesia is a type of anesthesia that is currently used for its technical ease and efficiency, performed in patients aged 6 months and older for its safety. Is headache a factor of importance to the point of impairing the postoperative recovery of patients? This questin led us to research the prevalence of post-spinal anesthesia headache in a Brazilian hospital. In general, this study aims to establish the prevalence of post-spinal headache in Gaffrée and Guinle University Hospital (HUGG) patients, Rio de Janeiro, Brazil. The prevalence of headache was also associated with social and professional variables and with the type of technique performed.

This is a sectional descriptive study. Data collection were carried out from August 2007 to February 2008. One hundred patients from both genders were included in this study ( $\mathrm{N}=100)$, with ages higher than or equal to 18 years. All of them were submitted to spinal anesthesia during different surgical procedures in the HUGG. In summary, the prevalence of post-puncture spinal headache (PPSH) in this study was 6\%, within acceptable limits found in the scientific medical literature. The prevalence of PPSH was higher among females and among white patients. The patients of the obstetric clinic were the ones that presented greater predominance of headache. The most important risk factors for headache were needle type and needle diameter.

\section{Introduction}

Headache is one of the most common symptoms in medicine in general, and one of the most frequent complaints in clinical, gynecological, pediatric and neurological consultations. It is a universal symptom and it is an extremely common condition in the world population. In several studies, the prevalence of headache over lifetime is over $90 \%$, causing impacts on the professional, social and, especially, on affective relationships of patients affected, being one of the most common causes of absenteeism and lack of schooling. In addition, many of those who work during a severe headache crisis have poor performance [1,2]. For some people, headache becomes a particular limiting condition, as it not only impairs the quality of their lives, but also directly affects their professional and social decisions, due to the loss of the capacity to plan and fulfill their commitments [1]. Headaches does not only affect the patients themselves, but all around them. Companions and children share the suffering manifested by the patient during crises and must be prepared for all the changes that occur in their daily lives, such as: leaving work early, changing plans regarding childcare and interrupting day-to-day activities. 
Patients feel the impact of this problem, especially during the crisis, developing psychological changes of anxiety, fear and uncertainty [3]. Headaches are divided into primary and secondary. The most common primary headaches are migraine, tension-type headache and cluster headache. Other less common forms include continuous hemicrania, new daily persistent headache, exertional headache, cough headache, cold-stimulating headache, and chronic paroxysmal hemicrania [4]. Headache specialists usually also treat facial pains such as trigeminal neuralgia, atypical facial pain, and myofascial pain. Secondary headaches are those caused by some other disease, such as brain neoplasms, head trauma, meningitis, stroke (stroke), hydrocephalus, and aneurysms. Headache from spinal anesthesia is included in this second classification and is known as post-puncture headache. It represents the most frequent neurological complication of spinal anesthesia, being highly disabling in some cases [5]. Spinalgesia or Spinal Anesthesia or Subarachnoid Anesthesia (AS) is one of the oldest methods of pain relief in surgical patients. Spinal anesthesia is a type of anesthesia that is currently used for its technical ease and efficiency, performed in patients aged 6 months and older for its safety.

Among the rare complications, the most frequent is headache $[6,7]$, which has a diagnostic criterion to be followed. The Subcommittee on Classification of Headaches of the International Headache Society classifies it as secondary headache. This type of headache is attributed to non-vascular intracranial disorder due to cerebrospinal fluid hypotension and should include the following diagnostic criteria: headache worsens within 15 minutes after standing and improves in 15 minutes at bedtime. It is associated with one of the following symptoms: neck stiffness, tinnitus, hearing loss, photophobia or nausea and should meet the following criteria:

a) Appear within five days after the puncture lasts.

b) Disappear spontaneously within one week or within 48 hours after effective treatment of spinagesia extravasation. In case the headache persists, this relationship is in doubt [8]. Many studies have been carried out to determine the prevalence of this symptom worldwide [9-11]. The fact that we have little knowledge about the triggering factors, the epidemiological clinical characteristics and the impact of headache on the patients of the different clinics of this hospital, justifies this investigation. Hence many questions arise: Is headache a factor of importance to the point of impairing the postoperative recovery of patients? These questions led us to research the prevalence of post-spinal anesthesia headache at the Gaffrée and Guinle University Hospital (HUGG). Therefore, we started to stimulate the search for measures to minimize this problem and to arouse the scientific interest for the subject.

\section{Objective}

In general, this study aims to establish the prevalence of postspinal headache in patients from the HUGG. More specifically, we investigated possible associations of technical, socio-demographic and epidemiological characteristics of patients submitted to spinal anesthesia in HUGG with the prevalence of headache and the repercussion of this pain in the postoperative recovery.

\section{Methodology}

After being approved and released by the Research Ethics Committee of the Gaffrée and Guinle University Hospital (HUGG)Federal University of the State of Rio de Janeiro (UNIRIO) and after the patient's signature of the free and informed consent form, we began this research, which is a sectional descriptive one. Data collection were carried out from August 2007 to February 2008. One hundred patients from both genders were included in this study $(\mathrm{N}$ $=100$ ), with ages higher than or equal to 18 years, submitted to spinal anesthesia during different surgical procedures in the HUGG. During this period, there were a total of 742 anesthetic procedures at the hospital, of which 252 were general anesthesia (33.96\%), 220 were spinal anesthesia (29.64\%) and 270 others $(36.96 \%$ - epidural, retrobulbar, sedation and local sedation). These data were taken from the register of the nursing service, in which all the interventions that took place in the surgical center are recorded. Despite the total number of 220 spinal anesthesia's, for several reasons, we were only able to include in our study one hundred patients. Among problems we faced during data collection, it is worth mentioning patients that refused to sign the consent term and other ones that were discharged earlier than initially predicted.

This study was carried out by the Discipline of Anesthesiology, in association with the Anesthesiology Service of the HUGG and with the permission of the surgeons who agreed to submit the patients to a questionnaire for data collection. After completing the questionnaire, patients were instructed to communicate with the investigator by phone, in case there were any complications such as nausea, vomiting and mainly headache within seven days after the procedure. Besides that, on the seventh day after the anesthesia, the researcher in charge would contact each patient to close the follow-up of the study. The diagnosis of headache was obtained after the patient had been submitted to the questionnaire on headache diagnosis criteria according to the International Headache Subcommittee and confirmed by the neurologist in charge by clinical examination. According to the intensity of the pain: absent, mild, moderate or intense, which was performed by submitting the patient to the verbal scale of pain and/or verbal numerical scale, the most appropriate treatment was prescribed.

The $\mathrm{p}$ values were calculated based on Student's t-test and $\mathrm{p}$ values less than 0.05 were considered significant. The procedures were performed in accordance with the ethical standards of the institution and of the national guidelines for human research. The study protocol was approved by the local ethics committee (HUGG).

\section{Result}

Only six among one hundred patients included in this study developed post-anesthesia headache. This being the case, we divided 
these patients in 2 two different groups: headache and non-headache. Follows the description of these two groups and their statistical comparisons. Headache-Six patients reported post-anesthesia headache. Five out of these six patients were woman and all of them were white. Their weight was (mean/SD) $65.2 \pm 13.0 \mathrm{~kg}$ height $163.0 \pm 10.1 \mathrm{~cm}$, body mass index $24.32 \pm 2.2$ and their age was $37.8 \pm 17.7$ years. Also, four out of these six patients had a minimum wage per month, one received 3 minimum wages per month, and one was unemployed. Regarding marital status, five were married and one was single. None of them were smokers. Four out of these six patients were submitted to gynecological procedures, one to prostatectomy and another one to varicose veins surgery. Regarding puncture technique, four of them were submitted to middle spinal anesthesia and two to paramedian spinal anesthesia. The prevailing position among this group of patients was lateral decubitus ( 4 patients) and only two of them were anesthetized in a sit position.

Five of these patients were punctured with Quincke needles and only one was punctured with Tuohy. Needle gauge was 25 for four patients, 18 for one patient and 27 for another one of them. All of these six patients had CSF hypotension. Non-headache - Ninety-four patients reported no headache. Sixty-six out of these ninety-four patients were woman. 76 patients were white and 18 were black. Their weight was (mean/SD) $71.6 \pm 13.8 \mathrm{~kg}$, height $164.0 \pm 7.7 \mathrm{~cm}$, body mass index [12]. $64 \pm 5.3$ and their age was $44.3 \pm 17.8$ years. Sixty-one out of these ninety-four patients were remunerated 1 to 3 minimum wages per month, nineteen patients had 4 to 5 minimum wages, six patients had 6 to 10 minimum wages per month and eight had no income at all. Regarding marital status, sixty-five patients were married, twenty were single and ten were widowers. Eighty-two of them were non-smokers and twelve were smokers. Sixty-three out of these ninety-four patients were submitted to gynecological procedures, fourteen to prostatectomy and seventeen to varicose veins surgery. Regarding puncture technique, fifty-nine of them were submitted to middle spinal anesthesia and thirty-five to paramedian spinal anesthesia. The prevailing position among this group of patients was lateral decubitus ( 90 patients) and only four of them were anesthetized in a sit position.

Ninety-two of these patients were punctures with Quincke needles and only two were punctured with Tuohy. Needle gauge was 25 for seventy-seven patients, gauge 27 for sixteen patients and gauge 29 for another one of them. Headache group versus Non-headache group comparisons-groups presented no difference regarding age $(\mathrm{p}=0.46)$, height $(\mathrm{p}=0.77)$, weight $(0,30)$ and BMI $(0,30)$, gender (0.82), race (0.50), marital status (0.67) and monthly income (0.99).Regarding puncture technique, variables type of needle (0.001) and needle gauge (0.000) demonstrated differences among groups, being Quincke more frequently used in patients from the non-headache group and gauge 25 also has been used more frequently in patients from this same group.

\section{Discussion}

The occurrence of post-spinal anesthesia headache is higher in females, according to the medical literature $[7,13,14]$. In this study, proportionally, headache after spinal anesthesia was higher in women also, however, the difference was not significant. Moreover, there are no scientific studies relating race to post-spinal headache. Here, we observed that, considering the variable race, there was an initial prevalence of more white patients when compared to the black ones, but it was not significant. In this study, there was a higher incidence of headache in married patients, which is also $71 \%$ of the general sample, but proportionally greater than $7.0 \%$ if related to $5 \%$ of unmarried individuals, however it was not statistically significant. Regarding the level of education of patients, there are no references in the specialized literature, this study shows a higher prevalence of college graduated patients. In the variable occupancy we can observe that this study did not find reference in the literature and that the patients most prone to headache were those with domestic occupation. Regarding the monthly income, the study showed a predominance of incomes from 1 to 3 minimum wages, headache was more prevalent $(9.5 \%)$ in the family income from 4 to 5 minimum wages proportionally.

Correlating patients' lifestyle data, no reference was found in the literature. In this study, it was observed that no patient who developed headache had any type of addiction (tobacco). The history of previous headache was considered important in this study as a predisposing variable for post-spinal anesthesia headache at $28 \%$ of the sample. Patients with no prior history of headache, which accounted for $72 \%$, occurred in $4.1 \%$ of this sample. There is no consensus that prior headache is a risk factor [15]. These results were obtained from a public hospital and we could not observe many statistically significant differences in our sample. When we observed the anesthetic technique performed, we found the median spinal anesthesia was performed in sixty-three patients, of which four developed post-spinal anesthesia headaches. The paramedian technique was performed in two patients placed in the headache group and in twety-four patients of the non-headache group. Proportionally, there was a higher prevalence of headache in the paramedian technique, a fact that can be explained by technical reasons such as: in one of these cases several punctures occurred; in another case, with a large diameter needle, the prevalence was higher.

It is postulated that paramedian punctures have a lower risk of post-puncture headache6, but not all studies confirm this. A similar incidence of headache was observed after median and paramedian puncture. A paramedian puncture study comparing 26G Atraucan and 27G Whitacre needles showed a 1\% CPPD rate 915, while the comparison of $27 \mathrm{G}$ Quincke needles with 25G Atraucan, with paramedian puncture, showed that the prevalence of headache was $0.4 \%$ [16]. In our study, this technique was not significant factor for headache incidence. Regarding the clinics, this study obtained a 
greater number of anesthesia's performed in the obstetric clinic and two patients in this clinic needed to remain hospitalized for seven days for conservative headache treatment. The scientific medical literature states that the obstetric patient is more susceptible to this type of complication. Many studies report that gestation is one of the factors of higher frequency of headache $[7,12,17]$. When we considered the types of needles used to perform spinal anesthesia, a strong factor for the development of post-spinal anesthesia, we observed that $97 \%$ of the patients were punctured with a Quincke needle in the headache group.

When using Quincke needle, it is advisable to puncture the dura with the bevel parallel to the longitudinal direction of the fibers $[6,10,18,19]$, a procedure that will cause a smaller section of these fibers, reducing trauma and loss of CSF and, consequently, headache. This technique is significant for the reduction of CPPD despite the sectioning of the fibers 7 . We observed a significant $\mathrm{p}=$ 0.001 for needle type. The diameter of the needle is a major factor in the occurrence of headache, especially in young patients over 20 years old $[13,20]$. In this work, there was a prevalence of headache of $4.9 \%$ with a needle of diameter 25 , which is in agreement with authors in the medical literature $[7,9,21]$, and the same result was not observed with that of gauge 27 , which can be explained by the higher number of puncture attempts with longer dura mater, in agreement with authors. In the use of sharp needles with a thin diameter, the occurrence of headache was similar [22]. Our research observed a significant value of $p=0.003$ for needle gauge when comparing the two groups. This result is in agreement with the literature $[6,7,23,24]$.

A significant factor in the onset of post-spinal anesthesia, is the number of dura mater punctures with perforation of the arachnoid $[10,25]$. Some headaches reported in this study occurred after the patient was punctured more than once. In this study, the mean age of the patients was higher than that used by other authors [26,27], while other studies observed similar ages to ours [9]. The weight of patients included in this study is similar to that found in other studies in the literature $[15,19]$ and it is directly related to the origin of the headache, since it may influence the CSF pressure. The BMI index was included in this study, but this indicator was not found in the literature as a reference for the origin of the headache. However, we can observe that the mean is slightly above normal in relation to the upper limit of normality, and may have influenced the incidence of headaches, since obstetric patients tend to gain weight during pregnancy.

\section{Conclusion}

In summary, the prevalence of post-puncture spinal headache (PPSH) in this study was 6\%, within acceptable limits found in the scientific medical literature. The prevalence of PPSH was higher among females and among white patients. The patients of the obstetric clinic were the ones that presented greater predominance of headache. The most important risk factors for headache were needle type and needle diameter. Regarding the level of education, the study identified $41 \%$ of the sample having completed high school and found unemployment in $29 \%$ of the patients. Family income ranges from 1 to 3 minimum wages to $65 \%$ of the sample and $71 \%$ are married. The headache delayed the hospital discharge of 2 patients who were hospitalized for a period of seven days for treatment.

\section{Acknowledgement}

None.

\section{Conflict of Interest}

No conflict of interest.

\section{References}

1. Bigal ME, Bigal JOM, Bordini CA, Speciali JG (2000) Avaliação da utilização do placebo nas crises agudas de migrânea sem aura, migrânea com aura e cefaléia tipo tensional episódica. Arq Neuro-Psiquiatr, São Paulo, Brazil, 59(20).

2. Catharino AMS, Catharino FMC, Alvarenga RMP, Fonseca RL (2007) Cefaléia: prevalência e relação com o desempenho escolar de estudantes de medicina. Migrâneas \& Cefaléias10(2): 46-50.

3. Bigal ME, Fernandes LC, Moraes FA, Bordoni CA, SpecialijG (2000) Prevalência e impacto da migrânea em funcinários do hospital das clínicas da faculdade de medicina de Ribeirão Preto - USP. Arq. NeuroPsiquiatr., São Paulo, Brazil, 58: 431-436.

4. Galdinog S, Albuquerque TIP, Medeiros TLA (2007) Cefaléias primárias: abordagem diagnóstica por médicos não-neurologistas. Arq NeuroPsiquiatr 65: 3.

5. Pedrosa GC, Jardim JL, Palmeira MA (1996) Tampão sangüíneo peridural e alta hospitalar precoce: Analise de 60 pacientes portadoras de cefaléia pós raquianestesia. Rev Bras Anestesiol 6(1): 8-12.

6. Ganem EM, Castiglia YMM, Vianna PTG (2002) Complicações neurológicas determinada pela anestesia subaracnóidea. Rev Brás Anestesio 52(4): 471-480.

7. Imbelloni LE (2001)Tratado de anestesia raquidiana. Curitiba: Medidática Informática 178-187.

8. (2006) Subcomitê De Classificação Das Cefaléias Da Sociedade Internacional De Cefaléia. Classificação internacional das cefaléias. (2 ${ }^{\text {nd }} E d n$.). Trad Sociedade Brasileira de Cefaléia. Alaúde (Eds.). Ltda, São Paulo, Brazil.

9. Amorim JA, Damázio FO, Maciel CMC, Santos GHA, Valença MM (2006) Cefaléia pós-raquianestesia: Prevalência e Fatores de Risco Serviço de Anestesiologia Hospital da Restauração/Hospital Getulio Vargas e Serviço de Neurologia e Neurocirurgia Federal de Pernambuco. Anais do XX Congresso Brasileiro de Cefaléia.

10. Imbelloni LE, Carneiro ANG (1997) Cefaléia pós-raquianestesia: causas, prevenções e Tratamento. Rev Bras Anestesiol 47(5): 453-464.

11. Neves JFNP, Vieira VLR, Saldanha RM, Vieira FAD, Coutinho NM, et al. (2005) Uso da hidrocortisona no tratamento e na prevenção da cefaléia pós-punção da dura-máter: relato de casos. Rev. Bras. Anestesiol 55(3): $343-349$.

12. Luostarinen L, Heinonen T, Luostarinen M, Salmivaara A (2005) Diagnostic Lumbar puncture. comparative study between 22-gauge pencil point and sharp bevel needle. J headache and Pain., Springer Mailand6(5): 400-404.

13. Morgan GJ, Mikhail MS (2003)Anestesiologia clínica. (2 ${ }^{\text {nd }}$ Edn.). Rio de Janeiro, Revinter, pp. 209-219.

14. Neves JFNP, Monteiro GA, AlmeidaJR, Brun A, Santanna RS (2001) Raquianestesia com agulha de Quincke 27G, 29g e whitacre 27G. 
Analise de Dificuldade técnica, Incidência de falhas e Cefaléia. Rev Bras Anestesiol 51(3): 196-201

15. Halpern S, Preston R (1994) Postdural puncture headache and spinal needle desgn metaanalyses. Anestesiology 81(6): 1376-1383.

16. Imbelloni LE (1997) Comparação entre Agulhas 27G whitacre com $26 \mathrm{G}$ Atraucan para cirurgias Eletivas em Pacientes abaixo de 50 Anos. Rev. Bras. Anestesiol 47(4): 288-296.

17. Chaves MM, Gusman PBEM, Manica J (2004) Anestesiologia: Princípios e Técnicas, (3 ${ }^{\text {rd }}$ Edn.). Porto Alegre, Artmed, pp. 691-694.

18. Richmam JM, Joe EM, Cohen RBS, Ronlingsom AJ, Michaels RK, et al. (2006) Bevel Direction and Postdural Puncture Headache: A MetaAnalysis. Neurologist 12(4): 224-228.

19. Tarkkila PJ, Heine H, Tervo RR (1992) Comparison of sprotte and Quincke needles with respect to pot durai puncture headache and backache. Reg. Anesth 17(5): 283-287.

20. Ortega JP, Garcia MAE, Araúzo P, Gómez MC, Munoz RL, et al. (1999) Incidência de cefalea Postpunción Durai Y Dolor Lumbar Trás Anestesia Intradural em Pacientes Menores de 25 anos. Rev Soc Esp Dolor 6: 96101.

21. Ahmed SV, Jayawarna C, Jude E (2006) Post lumbar puncture headache: diagnosis and management. Postgraduate Medical Journal 82(973): 713-716.

ISSN: 2574-1241

DOI: 10.26717/BJSTR.2019.22.003704

Ribeiro de Noronha SM. Biomed J Sci \& Tech Res

This work is licensed under Creative Commons Attribution 4.0 License

Submission Link: https://biomedres.us/submit-manuscript.php
22. Fernandez RD, Madrid MLT, Torrente PC, Mur TS (2003)Comparición de dos agujas de calibre $27 \mathrm{G}$ para anestesia raquidea. Estudio sobre 1555 pacientes. Rev Esp Anestesio! Reanim 50: 182-187.

23. Sadeq AQ, Hershey MS (2005) Abducens palsy Following Spinal Anesthesia: Mechanism, Treatment and Anesthetic considerations. Med. Gen. Med 7(4): 16

24. Choi PT, Galinski SE, Takeuchi L, Lucas S, Tamayo L, et al. (2003) PDPH is a Common complication of neuroaxial blockade in parturients: a metaanalisis of obstetrical studies. Can J Anest 50: 460-469.

25. Tsen LC, Hepner DL (2006) Needles used for spinal anesthesia. Exp Rev Med Dev 3(4): 499-508.

26. Villar GCP, Rosa C, Cappelli EL, Cest M (1999)Incidência de cefaléia pósraquianestesia em pacientes obstétricas com agulha de Whitacre Calibre 27 G -experiência com 4570 casos. Rev Bras Anestesiol 49(2): 110-112.

27. Luostarinen L, Heinonen T, Luostarinen M, Salmivaara A (2005) Diagnostic Lumbar puncture. comparative study between 22-gauge pencil point and sharp bevel needle. J headache and Pain Springer Mailand 6(5): 400-404.

$\begin{array}{ll}\text { BIOMEDICAL } & \text { Assets of Publishing with us } \\ \text { RESEARCHES } & \text { - Global archiving of articles } \\ & \text { - Immediate, unrestricted online access } \\ & \text { - Rigorous Peer Review Process } \\ & \text { - Authors Retain Copyrights }\end{array}$

